\title{
THE EFFECT OF ISO-BUTANOL-DIESEL BLENDS ON ENGINE PERFORMANCE
}

\author{
Mohammad Ibrahim Al-Hasan, Muntaser Al-Momany \\ Dept of Mechanical Engineering, Al-Balqa' Applied University, P.O. Box 15008 Amman, 11134 Jordan \\ E-mails: ${ }^{1} d r \_a l \_h a s a n @ h o t m a i l . c o m ;{ }^{2}$ eng_muntaser@hotmail.com
}

Received 20 January 2008; accepted 3 October 2008

\begin{abstract}
The effect of iso-butanol addition to diesel fuel on engine performance parameters has been experimentally investigated. The used engine was a single cylinder four stroke CI engine Type Lister 1-8. The tests were performed at engine speed that ranges from 375 to 625 with an increment of $42 \mathrm{rpm}$ at different loads and with 10, 20,30 and 40\% $\mathrm{v} / \mathrm{v}$ iso-butanol-diesel fuel blends. The overall engine performance parameters measured included air-fuel ratio (AFR), exhaust gas temperature, brake power $\left(B_{p}\right)$, brake specific fuel consumption $(b s f c)$ and brake thermal efficiency $\left(\eta_{t h}\right)$. The experimental results show that $A F R$, exhaust gas temperature, $\left(B_{p}\right)$ and $\left(\eta_{b t h}\right)$ decreased and bsfc increased with iso-butanol addition compared to net diesel fuel. Also, the obtained results indicate that the engine performance parameters when using up to $30 \%$ iso-butanol in fuel blends are better than that of $40 \%$.
\end{abstract}

Keywords: alternative diesel fuel, alcohol, iso-butanol, fuel blends, engine performance.

\section{Introduction}

The high degree of the world's dependency on energy coupled with the foreseeable future depletion of the worldwide petroleum reserves have led to large efforts in search for alternative energy sources such as nuclear, geothermal, biomass source etc. Alcohols, biomass based fuels, either single or blended with conventional petroleum based fuels are the most important alternative fuels for internal combustion engines. Several alcohols have been used; those of major interest are methanol, ethanol, iso-butanol and methyl tertiary butyl ether. Their high flame speed and wide flammability ranges characterize alcohol fuels despite their low flame emissivity, so they are expected to show superior flame stability and emissions (Goodger 1980). However, there are some disadvantages of alcohol fuel. The most important drawbacks are metallic corrosion that occurs in the engine cylinder and the deterioration of non-metallic parts in the fuel system

There are numerous investigations carried out on spark ignition and compression ignition engines to predict engine performance and exhaust emissions by using alcohol fuels (methanol and ethanol) blended with gasoline and /or diesel fuels (Lingaitis and Pukalskas 2008; Butkus et al. 2007; Mickūnaitis el al. 2007; Labeckas et al. 2006; Lebedevas and Vaicekauskas 2006; Lebedevas et al. 2006 and 2007; Raslavičius and Markšaitis 2007; Hsieh et al. 2002; Bilgin et al. 2002; Al-Hasan 2003; Satgé de Caro et al. 2001; Abu-Quadais et al. 2000; Gautam et al. 2000; Choi and Reitz 1999; Ajav et al. 1998 and 1999 etc.). A limited number of studies have been previously undertaken to evaluate the suitability of iso-butanol as an alternative fuel for spark ignition engines (Andziulis 2006; Alasfour 1997; Popuri and Bata 1993; Rice et al. 1991; Bata et al. 1989a and 1989b). Most of these studies have shown that alcohol fuels can have a level of performance comparable to that of diesel and gasoline fuels.

However, very few studies have been undertaken to investigate the performance characteristics of iso-butanol as an alternative fuel for diesel engines. This study is an investigation into the evaluation possibilities of isobutanol as an alternative to diesel fuel. Diluting 10, 20, 30 and $40 \% \mathrm{v} / \mathrm{v}$ iso-butanol with diesel fuel prepared fuel blends. This experimental work covered the determination of the fuel properties and engine performance test of diesel fuel and fuel blends.

\section{Materials}

Iso-butanol-diesel fuel blends were prepared by adding $10,20,30$ and $40 \% \mathrm{v} / \mathrm{v}$ industrial grade pure iso-butanol $\left(\mathrm{C}_{4} \mathrm{H}_{9} \mathrm{OH}, 99.5 \%\right)$ to diesel fuel obtained from the Jordan Petroleum Refinery Company. The chemical and physical properties of iso-butanol, diesel fuel and its blends are listed in Table 1. Stoichiometric air-fuel ratio $(A F R)_{\text {st }}$ for fuels has been calculated using Eqs. 1 and 2 and for 
Table 1. Fuel properties

\begin{tabular}{|c|c|c|c|c|c|c|c|}
\hline \multirow{3}{*}{\multicolumn{2}{|c|}{ Property }} & \multicolumn{6}{|c|}{ Fuel types } \\
\hline & & \multirow{2}{*}{ Diesel } & \multirow{2}{*}{ Iso-butanol } & \multicolumn{4}{|c|}{ Iso-butanol, $v / v, \%$} \\
\hline & & & & 10 & 20 & 30 & 40 \\
\hline Chemical formula & & $\mathrm{C}_{12.35} \mathrm{H}_{21.76}$ & $\mathrm{C}_{4} \mathrm{H}_{9} \mathrm{OH}$ & - & - & - & - \\
\hline Molecular weight, $\mathrm{kg} / \mathrm{kmol}$ & & 170.269 & 74.124 & - & - & - & - \\
\hline \multirow{4}{*}{$\begin{array}{l}\text { Gravimetric elemental } \\
\text { analysis, \% m }\end{array}$} & Carbon & 87.12 & 64.82 & \multirow{4}{*}{-} & \multirow{4}{*}{-} & \multirow{4}{*}{-} & \multirow{4}{*}{ - } \\
\hline & Hydrogen & 12.88 & 13.60 & & & & \\
\hline & Sulfur & 1.095 & 0 & & & & \\
\hline & Oxygen & 0 & 21.58 & & & & \\
\hline \multicolumn{2}{|l|}{ Stoichiometric air-fuel ratio } & 14.5 & 11.2 & - & - & - & - \\
\hline \multicolumn{2}{|l|}{ Lower heating value, $\mathrm{MJ} / \mathrm{kg}$} & 42.93 & 33.64 & 42 & 41.2 & 40.2 & 39.3 \\
\hline \multicolumn{2}{|l|}{ Liquid density, $\mathrm{kg} / \mathrm{m}^{3}$} & 829 & 800 & 826 & 823 & 820 & 817 \\
\hline \multicolumn{2}{|c|}{ Latent heat of vaporization, $\mathrm{MJ} / \mathrm{kg}$} & 0.375 & 0.57 & - & - & - & - \\
\hline \multicolumn{2}{|l|}{ Boiling point, ${ }^{\circ} \mathrm{C}$} & $210-235$ & 117 & - & - & - & - \\
\hline
\end{tabular}

fuel blends Eq. 4. Lower heating value (LHV) has been determined from the Mendeleyev formula Eq. 3.

$$
\begin{aligned}
& \mathrm{C}_{4} \mathrm{H}_{9} \mathrm{OH}+6\left(\mathrm{O}_{2}+3.773 \mathrm{~N}_{2}\right)= \\
& 4 \mathrm{CO}_{2}+5 \mathrm{H}_{2} \mathrm{O}+22.64 \mathrm{~N}_{2} \\
& \mathrm{C}_{12.4} \mathrm{H}_{21.8}+17.8\left(\mathrm{O}_{2}+3.7 \mathrm{~N}_{2}\right)= \\
& 12.4 \mathrm{CO}_{2}+10.9 \mathrm{H}_{2} \mathrm{O}+67 \mathrm{~N}_{2}, \\
& L H V=33.9 \mathrm{C}+125.6 \mathrm{H}- \\
& 10.9\left(\mathrm{O}_{\mathrm{y}}-\mathrm{S}\right)-2.5(9 \mathrm{H}-\mathrm{W}) \\
& (L H V)_{b}=\sum\left(\rho_{i} \times v_{i} / \rho_{i}\right)(L H V)_{i},
\end{aligned}
$$

where: $\mathrm{C}, \mathrm{H}, \mathrm{O}_{\mathrm{y}} \mathrm{S}$, and $\mathrm{W}$ represent the elemental composition of fuels.

\section{Experimental Apparatus and Procedures}

\subsection{Apparatus}

An experimental apparatus included two major systems, i.e. the engine system and the dynamometer system. The engine used in this experiment was a single cylinder four stroke diesel engine type Lister 8-1 TE 9. The engine swept volume was $1433 \mathrm{~cm}^{3}$; the maximum power of 8 - $\mathrm{HP}(6 \mathrm{~kW})$ and the maximum engine speed is 850 $\mathrm{rpm}$. The engine was coupled to the electrical dynamometer (type B.K.B. Compound) that can be used to absorb the power developed by the engine and as a motor for starting the engine. Dynamometer maximum speed is $2500 \mathrm{rpm}$ and the speed ratio dynamometer to the engine was 2.4:1. Dynamometer load was controlled by a separately mounted loading electrical unit consisting of 10 cells (i.e. electrical resistances). Dynamometer load in Newton and speed in rpm can be directly measured. Engine brake torque was calculated using dynamometer load and the arm radius of $220 \mathrm{~mm}$. The air consumption meter type TE 40 was used to measure the airflow of the engine. The meter consists of a surge air box connected to the engine air inlet and fitted with a circular sharp-edge measuring orifice of $32 \mathrm{~mm}$ in diameter with a discharge coefficient of 0.6 located upstream of the air box. Pressure drop across the orifice was measured by an inclined manometer capable of reading $1 \mathrm{~mm} \mathrm{H}_{2} \mathrm{O}$. The fuel volume flow rate was measured using a stopwatch and a calibrated glass tube divided into three sections 25 , 50 and $75 \mathrm{~cm}^{3}$. Thermocouple type $K$ was used to measure exhaust gas temperature. The schematic diagram of the experimental set up is shown in Fig. 1.

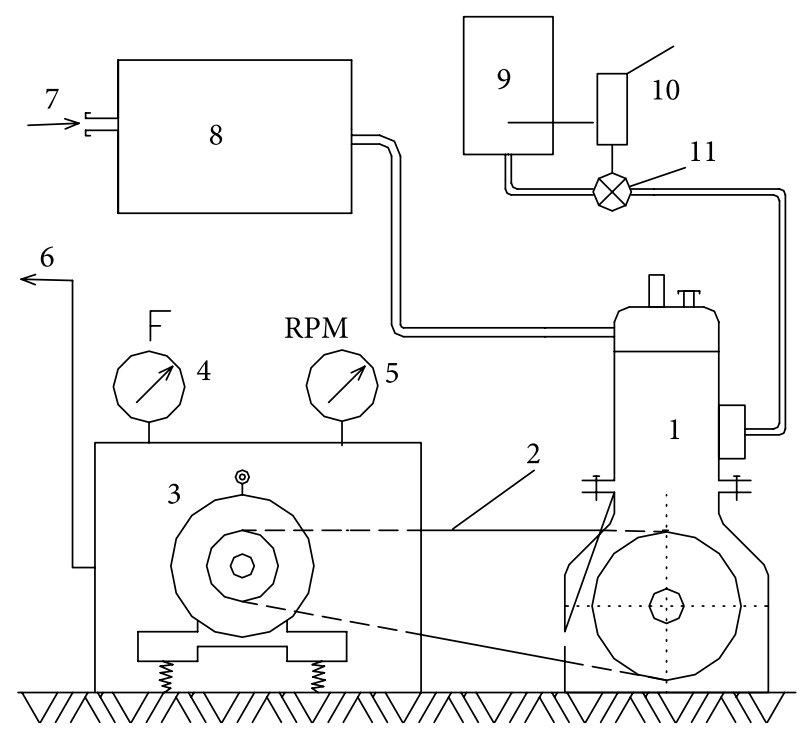

Fig. 1. Experimental engine and associated equipment: 1 - CI engine; 2 - coupling belt; 3 - electrical dynamometer; 4 - load indicator; 5 - dynamometer speed indicator; 6 - to the control system; 7 - air inlet; 8 - surge air box;

9 - fuel tank; 10 - calibrated glass tube; 11 - valve

\subsection{Procedures}

The engine performance carried out with fuel blends was accomplished under conditions similar to those occurring if the fuel was substituted for diesel fuel without any modification to the engine.

The tests were performed at engine speed ranges from 375 to $625 \mathrm{rpm}$ with an increment of $42 \mathrm{rpm}$ and at different loads. For each test the engine was initially warmedup and the required speed was obtained by changing the rack position of the high pressure diesel fuel pump. The 
required engine load was obtained through the electrical dynamometer control system. Before running the engine to a new fuel blend, it was allowed to run for sufficient time to consume the left fuel from the previous experiment. The operating conditions were stabilized and the variables that were continuously measured were recorded. This included dynamometer speed and load, time required to consume $25 \mathrm{~cm}^{3}$ of fuels $(t)$, pressure drop across the orifice $(h)$ and exhaust gas temperature for further analysis. For each experiment, three runs were carried out to obtain an average value of the experimental data.

The engine performance parameters such as fuel consumption rate $\left(m_{f}\right)$, air mass flow rate $\left(m_{a}\right)$, air fuel ratio $(A F R)$, brake power $\left(B_{P}\right)$, brake specific fuel consumption (bsfc) and brake thermal efficiency $\left(\eta_{b t h}\right)$ were estimated using the following equations:

$$
\begin{aligned}
& \dot{m}_{f}=\frac{3.6 \cdot Q_{f} \cdot \rho_{b}}{t}, \\
& \dot{m}_{a}=1.232 \cdot 10^{-5} \cdot D^{2} \cdot \sqrt{h \cdot \frac{p}{T}}, \\
& (A F R)_{a c}=\frac{\dot{m}_{a}}{\dot{m}_{f}}, \\
& B_{p}=\frac{N \cdot T}{9549.3}, \\
& b s f c=\frac{\dot{m}_{f}}{B_{p}}, \\
& \eta_{b t h}=\frac{3600 \cdot B_{p}}{\dot{m}_{f}} \cdot(L H V)_{b},
\end{aligned}
$$

where: $\rho$ is fuel density, $\mathrm{kg} / \mathrm{m}^{3} ; Q_{f}$ is the volume of fuel consumption, $\mathrm{cm}^{3} ; D$ is orifice diameter, $\mathrm{mm} ; P$ is atmospheric pressure, $\mathrm{Nm}^{-2} ; \mathrm{T}$ is surrounding temperature, $\mathrm{K}$; or torque, $\mathrm{Nm} ; \mathrm{N}$ is the engine speed, $\mathrm{rpm}$.

\section{Results and Discussion}

The effect of iso-butanol addition to diesel fuel on CI engine performance at different loads and at variable engine speed is investigated.

\subsection{Fuel Properties}

The properties of iso-butanol, diesel fuel and iso-butanol-diesel fuel blends are shown in Table 1. The lower heating value of iso-butanol is lower than that of diesel fuel. Therefore, the amount of iso-butanol should be 1.28 times greater than that of diesel fuel to achieve the same energy output. The stoichiometric air-fuel ratio of isobutanol was $73 \%$ of diesel fuel. Thus, the amount of the air required for complete combustion was lesser for isobutanol. The heat of iso-butanol vaporization was 1.62 times greater than that of diesel fuel. This means that the temperature of the air-fuel mixture in the engine cylin- der through the end of the compression stroke decreases due to the increase in the heat losses. Consequently, ignition time increases and the total ignition duration decreases (time interval between the beginning and the end of ignition) and as a result combustion temperature decreases. Oxygen content in iso-butanol was $22 \%$ which improved the diffusive combustion phase.

Also, as shown in Table 1, the lower heating values and the densities of iso-butanol-diesel fuel blends decrease as iso-butanol percentage in the blends increases which affects engine performance.

\subsection{Engine Performance}

The engine performance parameters obtained from the analysis of the experimental data are demonstrated in Figs. 2 to 6 and expressed in terms of the volume percentage of iso-butanol in fuel blends in order to quantify the effect of iso-butanol addition in diesel fuel on engine performance.

The effect of iso-butanol-diesel fuel blends on airfuel ratio is shown in Fig. 2. As shown in the figure, AFR decreases with the increase in the engine speed. Furthermore, AFR decreases with iso-butanol addition compared to pure diesel fuel. This behavior can be explained as follows: the air mass flow rate for each engine speed is constant, since $D, h, p$, and $T$ are constant (see Eq. 6); and the fuel mass flow rate increases with the increase in the engine speed and with iso-butanol addition. As a result, AFR decreases.

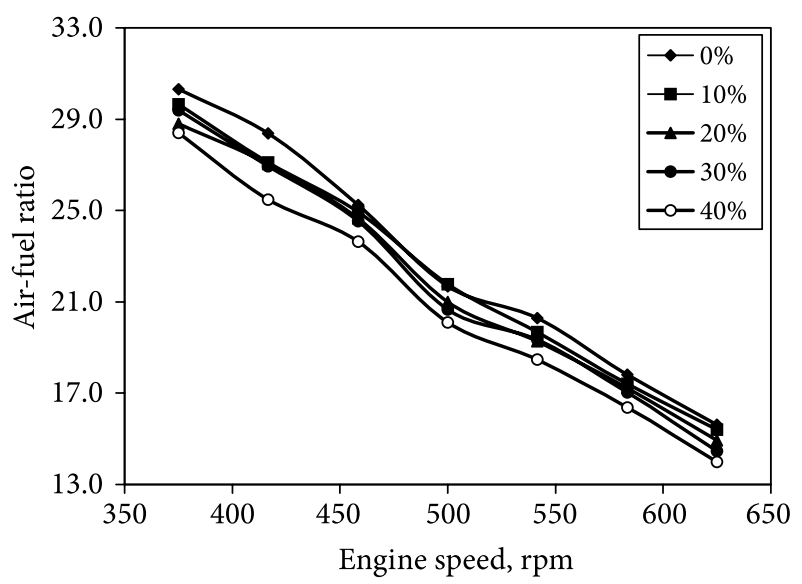

Fig. 2. Variation of air-fuel ratio as a function of the engine speed for different iso-butanol-diesel fuel blends

Exhaust gas temperature against the engine speed for different fuels is presented in Fig. 3. As shown in the figure, exhaust gas temperature increases as the engine speed increases in all tests. On the other hand, it is found that exhaust gas temperature decreases with iso-butanol addition in diesel fuel. This behavior can be attributed to the following factors: exhaust gas temperature is an indication of combustion temperature which is a function of ignition time. Diesel fuel has the smallest ignition time related to the fuel heat of vaporization and to the heating value. Therefore, as iso-butanol is blended with diesel fuel, combustion temperature and exhaust gas temperature decreases according to the percentage of iso-butanol 
in the blend. Furthermore, the decrease in exhaust gas temperature is more evident for $40 \%$ iso-butanol in the fuel blend. This behavior is expected because the amount of fuel consumed by the engine is higher than that of other fuel blends. Consequently, the heat losses (i.e. the increase in ignition time) and the decrease in the heating value increased; hence exhaust gas temperature decreases.

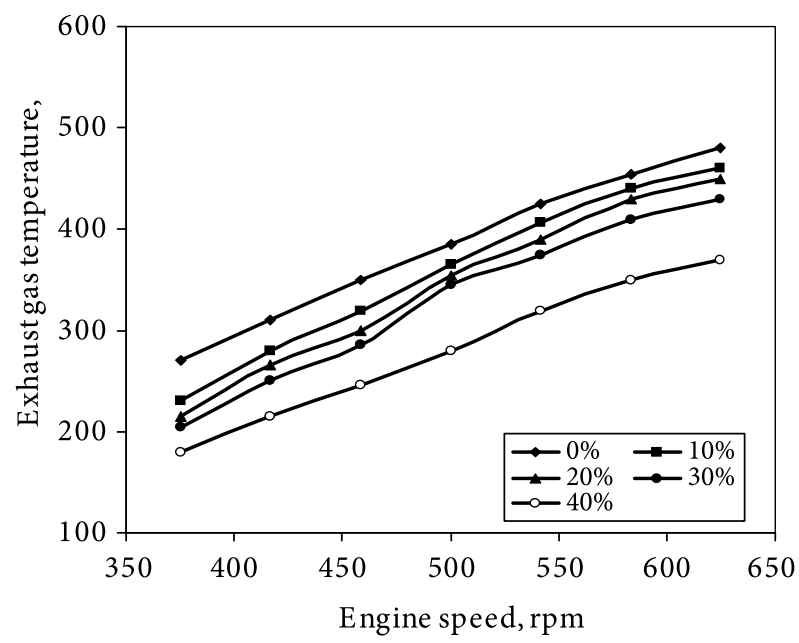

Fig. 3. Variation of exhaust gas temperature as a function of the engine speed for different iso-butanol-diesel fuel blends

Figure 4 shows engine brake power versus the engine speed for different fuel blends and neat diesel fuel. This figure clearly indicates that brake power increases as the engine speed increases for all fuels. Also, the figure presents that brake power with fuel blends decreases due to the decrease in air-fuel mixture temperature at the beginning of the combustion stroke resulted from the higher heat of iso-butanol vaporization. Consequently, combustion temperature decreases, and thus brake power decreases.

Figure 5 indicates the variation of $b s f c$ versus the engine speed for different fuels. As shown in the figure, $b s f c$ increases as the engine speed increases for all fuel blends. At the same time, it can be found that $b s f c$ also increases with iso-butanol addition in diesel fuel compared to neat

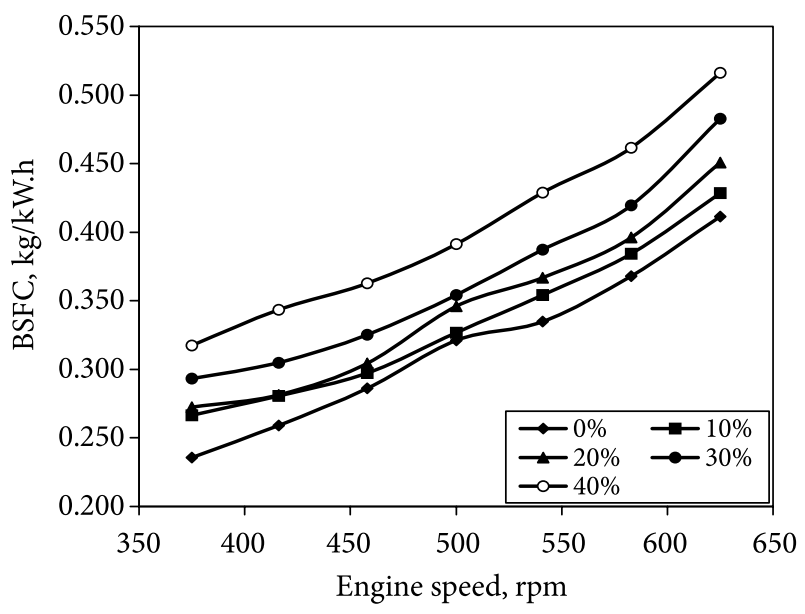

Fig. 4. Variation of brake power as a function of the engine speed for different iso-butanol-diesel fuel blends diesel fuel. This behavior was reasonable in view of the fact that the engine would consume more fuel with fuel blends than with neat diesel fuel to generate the same power output, due to the decrease in the lower heating value of fuel blends, hence the increase $b s f c$.

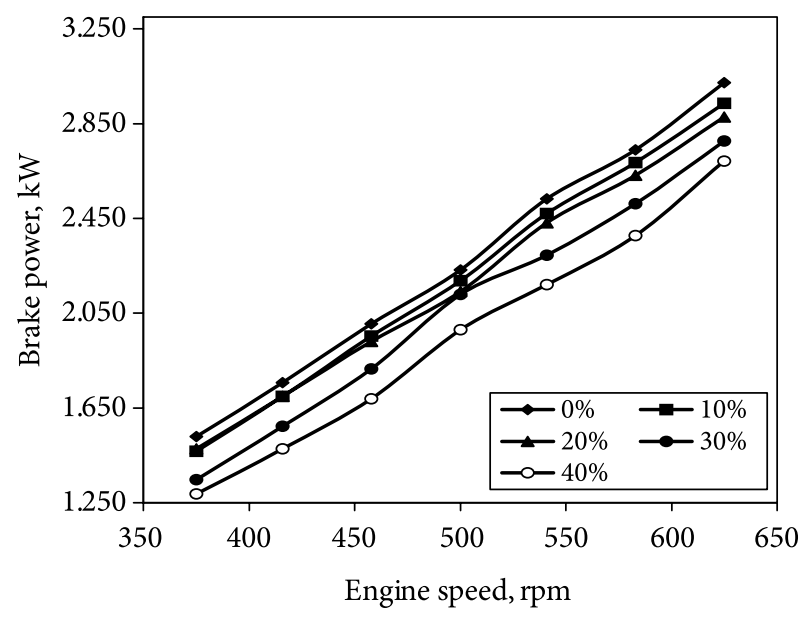

Fig. 5. Variation of brake specific fuel consumption as a function of the engine speed for different iso-butanol-diesel fuel blends

The effect of iso-butanol-diesel fuel blends on engine brake thermal efficiency $\left(\eta_{b t h}\right)$ at different engine speed is shown in Fig. 6. It is clear that $\eta_{b t h}$ decreases as the engine speed increases for all fuels. Also, contrary to the behavior of $b s f c, \eta_{b t h}$ showed a decrease in iso-butanol addition. However, for the engine speed of $500 \mathrm{rpm}$ and up to $30 \%$ of iso-butanol in fuel blends the decrease in $\eta_{b t h}$ is smaller than that of the other engine speed and fuel blends.

This can be attributed to a slight increase in $b s f c$, a slight decrease in exhaust gas temperature and AFR at this speed comparing to diesel fuel.

Moreover, as the percentage of iso-butanol increases in fuel blends up to $40 \%$, more decrease in $\eta_{b t h}$ is observed. This confirms the behaviour of exhaust gas temperature.

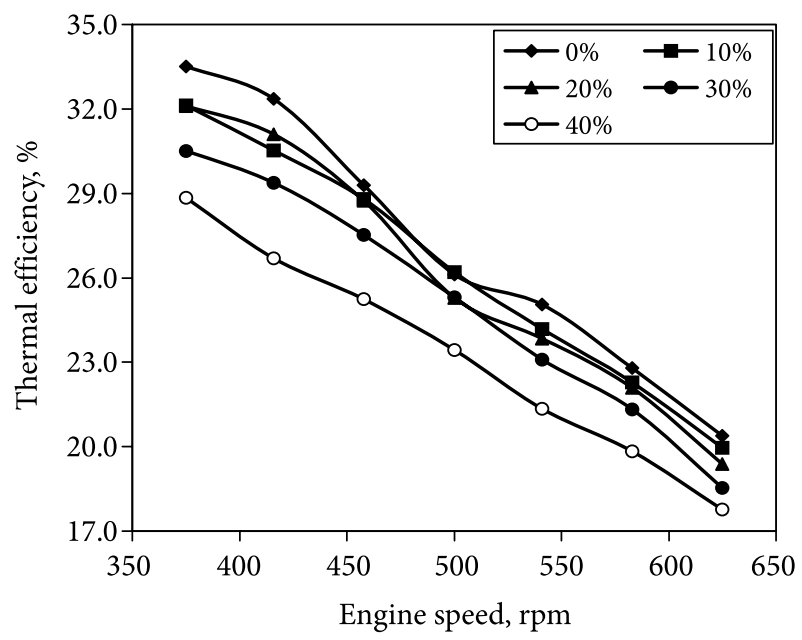

Fig. 6. Variation of brake thermal efficiency for different iso-butanol-diesel fuel blends 


\section{Conclusions}

The effect of iso-butanol addition to diesel fuel on a performance of a single cylinder compression ignition engine was investigated and compared to the base line diesel fuel. The main results obtained can be summarized as follows:

- as the engine speed increased exhaust gas temperature, brake power and brake specific fuel consumption are increased while air fuel ratio and brake thermal efficiency decreased for all fuel tested;

- air-fuel ratio decreases due to the increase in the fuel mass flow rate of fuel blends;

- exhaust gas temperature and brake power are decreased due to the increase in the heat of vaporizing fuel blends;

- brake specific fuel consumption increased due to the decrease in the lower heating value of fuel blends;

- brake thermal efficiency decreased due to the increase in brake specific fuel consumption and decrease in combustion temperature.

In general, the deviation of the engine performance parameters when using fuel blends is more evident with $40 \%$ iso-butanol addition to diesel fuel comparing with neat diesel fuel; therefore it can be concluded that up to $30 \%$ of iso-butanol can be added to diesel fuel to obtain the desired engine performance.

\section{References}

Abu-Quadais, M.; Hadad, O.; Qudaisat, M. 2000. The effect of alcohol fumigation on diesel engine performance and emissions, Energy Conversions and Management 41(4): 389-399.

Ajav, E. A.; Singh, B.; Bhattacharya, T. K. 1999. Experimental study of some performance parameters of a constant speed stationary diesel engine using ethanol-diesel blends as fuel, Biomass and Bioenergy 17(4): 357-365.

Ajav, E. A.; Singh, B.; Bhattacharya, T. K. 1998. Performance of a stationary diesel engine using vaporized ethanol as supplementary fuel, Biomass and Bioenergy 15(6): 493-502.

Alasfour, F. N. 1997. Butanol: a single cylinder engine study: Engine performance, International Journal of Energy Research 21(1): 21-30.

Al-Hasan, M. 2003. The effect of ethanol-unleaded gasoline blends on engine performance and exhaust emissions, Energy Conversions and Management 44(9): 1547-1561.

Andziulis A. 2006. Long-term oxidation stability of gasoline on account of MIR monitoring, Transport 21(3): 218-222.

Bilgin, A.; Durgun, O.; Sahin, Z. 2002. The effect of diesel-ethanol blends on diesel engine performance, Energy Sources 24(5): 431-440.

Bata, R. M.; Elrod, A. C.; Lewandowski, T. P. 1989a. Butanol as a blending agent with gasoline for IC engines, $S A E$ paper 890434.

Bata, R. M.; Elrod, A. C.; Lewandowski, T. P. 1989b. Evaluation of butanol as an alternative fuel, in Proceedings of 12th Annual Energy-Sources Technology Conference and Exhibition, Houston, 22-25 Jan 1989 (American Society of Mechanical Engineers, New York, 1989), 1-5.
Butkus, A.; Pukalskas, S.; Bogdanovičius, Z. 2007. The influence of turpentine additive on the ecological parameters of diesel engines, Transport 22(2): 80-82.

Choi, C. Y.; Reitz, R. D. 1999. An experimental study on the effect of oxygenated fuel blends and multiple injections on DI diesel engine emissions, Fuel 78(11): 1303-1317.

Gautam, M.; Martin, D. W.; Carder, D. 2000. Emissions characteristics of higher alcohol-gasoline blends, in Proceedings of the Institution of Mechanical Engineers - Part A - Power \& Energy 214(2): 165-182.

Goodger, E. M. 1980. Alternative fuels. The Macmillan Press LTD. London.

Hsieh, W.-D; Chen, R.-H.; Wu, T.-L.; Lin, T.-H. 2002. Engine performance and pollutant emission of an SI engine using ethanol-gasoline blended fuels, Atmospheric Environment 36(3): 403-410.

Labeckas, G.; Pauliukas, A.; Slavinskas, S. 2006. The effect of fuel additive SO-2E on diesel engine performance when operating on Diesel fuel and shale oil, Transport 21(2): 71-79.

Lebedevas, S.; Vaicekauskas, A. 2006. Research into the application of biodiesel in the transport sector of Lithuania, Transport 21(2): 80-87.

Lebedevas, S.; Vaicekauskas, A.; Lebedeva, G.; Janulis, P.; Makarevičienè, V. 2006. Research into operational parameters of diesel engines running on RME biodiesel, Transport 21(4): 260-268.

Lebedevas, S.; Vaicekauskas, A.; Suškov, P. 2007. Presumptions of effective operation of diesel engines running on RME biodiesel. Research on kinetics of combustion of RME biodiesel, Transport 22(2): 126-133.

Lingaitis, L. P.; Pukalskas, S. 2008. Ecological aspects of using biological diesel oil in railway transport, Transport 23(2): 138-143.

Mickūnaitis, V.; Pikūnas, A.; Mackoit, I. 2007. Reducing fuel consumption and $\mathrm{CO}_{2}$ emission in motor cars, Transport 22(3): 160-163.

Popuri, S. S. S.; Bata, R. M. 1993. A performance study of isobutanol-, methanol-, and ethanol-gasoline blends using a single cylinder engine, SAE paper 932953.

Raslavičius, L.; Markšaitis, D. 2007. Research into three-component biodiesel fuels combustion process using a single droplet technique, Transport 22(4): 312-315.

Rice, R. W.; Sanyal, A. K.; Elrod, A. C.; Bata, R. M. 1991. Exhaust gas emissions of butanol, ethanol, and methanolgasoline blends, Journal of Engineering for Gas Turbine and Power 113(3): 337-381.

Satgé de Caro, P.; Mouloungui, Z.; Vaitilingom, G.; Berge, J. C. 2001. Interest of combining an additive with diesel-ethanol blends for use in diesel engines, Fuel 80(4): 565-574. 